\title{
A Novel Calcium Oxalate/Sepiolite Composite for Highly Selective Adsorption of Pb(II) from Aqueous Solutions
}

\author{
Hui Xie $\mathbb{( 1 )}$, Shilin Zhang, Jingyan Liu, Jinqing Hu and Aidong Tang * $*$ \\ College of Chemistry and Chemical Engineering, Central South University, Changsha 410083, China; \\ xiehui@csu.edu.cn (H.X.); $182301039 @$ csu.edu.cn (S.Z.); LiuJingyan0901@csu.edu.cn (J.L.); \\ hujinqing@csu.edu.cn (J.H.) \\ * Correspondence: adtang@csu.edu.cn; Tel.: +86-731-8887-9616
}

check for updates

Citation: Xie, H.; Zhang, S.; Liu, J.; $\mathrm{Hu}, \mathrm{J}$.; Tang, A. A Novel Calcium Oxalate/Sepiolite Composite for Highly Selective Adsorption of $\mathrm{Pb}$ (II) from Aqueous Solutions. Minerals 2021, 11, 552. https://doi.org/ $10.3390 / \min 11060552$

Academic Editors: Francisco Franco, Manuel Pozo Rodríguez and Michael G. Stamatakis

Received: 23 April 2021

Accepted: 18 May 2021

Published: 23 May 2021

Publisher's Note: MDPI stays neutral with regard to jurisdictional claims in published maps and institutional affiliations.

Copyright: (c) 2021 by the authors. Licensee MDPI, Basel, Switzerland. This article is an open access article distributed under the terms and conditions of the Creative Commons Attribution (CC BY) license (https:/ / creativecommons.org/licenses/by/ $4.0 /)$.

\begin{abstract}
Synthesizing functional nanomaterials from naturally abundant clay has always been of vital importance for resource utilization, however, the lack of new methods to effectively utilize low-grade clay presents a significant challenge. Herein, a calcium oxalate/sepiolite nanocomposite $(\mathrm{SMN}-\mathrm{x})$ was prepared by using the water bath heating method to convert the associated calcium carbonate in low-grade sepiolite into calcium oxalate. The developed composite was subsequently used to remove $\mathrm{Pb}$ (II) from the aqueous solutions. The SMN-3 adsorbent prepared by heating in a water bath at $90^{\circ} \mathrm{C}$ for $3 \mathrm{~h}$ (with a high specific surface area of $234.14 \mathrm{~m}^{2} \cdot \mathrm{g}^{-1}$ ) revealed the maximum $\mathrm{Pb}$ (II) adsorption capacity of $504.07 \mathrm{mg} \cdot \mathrm{g}^{-1}$ at $\mathrm{pH} 5$, which was about five times higher than that of sepiolite $\left(105.57 \mathrm{mg} \cdot \mathrm{g}^{-1}\right)$. Further, the SMN-3 adsorbent possessed a much higher selectivity for $\mathrm{Pb}$ (II) as compared to the other metal ions. Moreover, the residue was noted to be stable and safe. The adsorption kinetics and isotherms conformed to the quasi-second-order kinetic and Langmuir models. During the adsorption process, ion exchange was noted to the main mechanism, however, it was also accompanied by electrostatic attraction. This study provides a novel strategy for the sustainable development of simple and efficient adsorbents by utilizing low-grade clay minerals.
\end{abstract}

Keywords: clay mineral materials; water chemistry; sepiolite; $\mathrm{Pb}(\mathrm{II})$; calcium oxalate; adsorption mechanism

\section{Introduction}

The alarming contamination of farmland and water resources with heavy metal ions has attracted significant research attention. Among the heavy metals, $\mathrm{Pb}$ (II) and its compounds are carcinogenic, highly toxic and non-degradable. These can accumulate inside the bodies of the animals, leading to renal failure and neurological damage [1-5]. The strategies currently used to remove the $\mathrm{Pb}$ (II) ions include chemical precipitation, the electrochemical method, membrane filtration, ion exchange and adsorption [6-11]. Adsorption represents a functional approach owing to its characteristics, such as simple operation, high efficiency, cost-effectiveness and absence of secondary pollution [1,12-14]. Development of high capacity and low cost adsorbents, especially based on clay, is the key to alleviate $\mathrm{Pb}(\mathrm{II})$ pollution.

The clay minerals are abundant and have low price, high specific surface area and significant adsorption characteristics [15,16]. Sepiolite, which is a 2:1 layered structure of two silicon-oxygen tetrahedron layers sandwiching a magnesium-oxygen octahedron layer, possesses the ideal molecular formula $\mathrm{Si}_{12} \mathrm{O}_{30} \mathrm{Mg}_{8}(\mathrm{OH})_{4}\left(\mathrm{H}_{2} \mathrm{O}\right)_{4} \cdot 8 \mathrm{H}_{2} \mathrm{O}$ [10-12]. Sepiolite is generally used as an adsorbent carrier due to its fibrous rod-like morphology and abundant surface Si-OH groups [17-19]. The sepiolite-based composite materials can be effectively used to remove the heavy metals from wastewater by employing different strategies, such as functional group modification, organic-inorganic compounding, etc. [20-22]. Sulfhydryl functionalized sepiolite [23] exhibits a high adsorption capacity of $97.00 \mathrm{mg} \cdot \mathrm{g}^{-1}$ for $\mathrm{Pb}$ (II) in the aqueous solutions. Further, $\mathrm{Fe}_{3} \mathrm{O}_{4}$ and $\mathrm{MnO}_{2}$-modified sepiolite [24] was used as a 
magnetic adsorbent to remove the $\mathrm{Pb}$ (II) ions from water in a batch system. The saturated adsorption capacity of the monolayer reached $131.58 \mathrm{mg} \cdot \mathrm{g}^{-1}$, along with an excellent cyclic stability. Using hexadecyl trimethyl ammonium bromide [25], chitosan, polyacrylic acid [26] and polypyrrole [27] to synthesize the organic-inorganic composites with sepiolite, both $\mathrm{Pb}$ (II) and $\mathrm{Cr}$ (VI) could be adsorbed, and the maximum $\mathrm{Pb}$ (II) adsorption capacity reached $638.90 \mathrm{mg} \cdot \mathrm{g}^{-1}$. Among the above sepiolite-based functional materials, it is necessary to purify low-grade sepiolite by methods such as flotation, acidolysis and thermal decomposition, and then proceed to the next step of functionalization. However, the purification processes are cumbersome, energy-consuming and costly. On the other hand, owing to the mechanism of formation and environment of the sepiolite clay, low-grade sepiolite is often accompanied by a large amount of mineral impurities (such as calcium carbonate), which becomes solid waste and is unfavorable for adsorption. $[15,28]$. Therefore, it is imperative to find a new method to effectively utilize carbonate in low-grade sepiolite for preparing a functional adsorbent.

There have been a lot of adsorption studies on sepiolite composites. However, this study innovated a strategy for the effective use of low-grade sepiolite with the associated calcium carbonate impurity. The calcium carbonate was converted into calcium oxalate by heating oxalic acid and sepiolite in a water bath, thereby leading to the generation of a novel calcium oxalate/sepiolite adsorbent. The effect of the co-thermal reaction duration in the water bath on the structure and performance of the developed adsorbent was evaluated. Further, the influence of the adsorption duration, initial concentration of the $\mathrm{Pb}(\mathrm{II})$ solution, initial $\mathrm{pH}$ and adsorbent amount on the adsorption performance was investigated. Moreover, the selectivity and safe performance of the adsorbent were evaluated. Finally, the adsorption mechanism was discussed on the basis of adsorption kinetics, adsorption isotherms and structural characterization.

\section{Materials and Methods}

\subsection{Materials and Chemicals}

Low-grade sepiolite was purchased from Hunan Xiangtan Sepiolite Technology Co., Ltd., Xiangtan, China. The content of calcium carbonate in each gram of sepiolite is $6.57 \%$ (based on mass fraction) as measured by experiments. Before use, the sepiolite was sifted with 200-mesh screen. All reagents used in the experiment, such as lead nitrate $\left(\mathrm{Pb}\left(\mathrm{NO}_{3}\right)_{2}\right)$, sodium hydroxide $(\mathrm{NaOH})$, oxalic acid dihydrate $\left(\mathrm{H}_{2} \mathrm{C}_{2} \mathrm{O}_{4}\right)$, and hydrochloric acid $(\mathrm{HCl})$ were obtained from Huihong Reagent Co, Ltd., Changsha, Hunan, China.

\subsection{Preparation of Calcium Oxalate/Sepiolite}

To begin, $1.0 \mathrm{~g}$ of the sieved low-grade sepiolite and $3.0 \mathrm{~g}$ of the oxalic acid dihydrate were added into a $100 \mathrm{~mL}$ beaker with $40 \mathrm{~mL}$ of deionized water and stirred in a $90^{\circ} \mathrm{C}$ water bath at different times. After centrifugation, the samples were washed with deionized water for several times until the $\mathrm{pH}$ was neutral, and dried at $80{ }^{\circ} \mathrm{C}$ for $12 \mathrm{~h}$ to obtain a series of calcium oxalate/sepiolite adsorbents (denoted as SMN-x, $x$ is water bath time, $\mathrm{x}=1,2,3,4,6 \mathrm{~h})$.

\subsection{Characterization of the Materials}

The composition of SMN-3 material was determined by X-ray diffraction (XRD, DX2700, Liaoning Dandong Haoyuan Instrument Co., Ltd, Dandong, China) with $\mathrm{Cu} \mathrm{K} \alpha$ radiation source $(\lambda=0.15418 \mathrm{~nm})$. The $\mathrm{KBr}$ tablet method was used to record the infrared spectrum of calcium oxalate/sepiolite adsorbent on a Fourier transform infrared spectrometer (FTIR, IR-960, Japan), with a wavenumber range of $4000-400 \mathrm{~cm}^{-1}$. The $\mathrm{N}_{2}$ adsorption/desorption isotherm was performed on a porosity analyzer (JW-BK-132F, Beijing Jingwei Gaobo Science and Technology Co., Ltd., Beijing, China) and the specific surface area and pore size distribution of the material were measured by Brunauer-EmmettTeller (BET) method. The Zeta potential of SMN-3 material was measured with a Zeta potential analyzer (Delsa 440SX, Backman-Coulter, Pasadena, CA, USA) in the pH range 
of 1-11. A field emission scanning electron microscope (SEM, Nano-230, FEI, Hillsboro, OR, USA) and a transmission electron microscope (TEM, Jem-2100F, JEOL, Tokyo, Japan) were used to measure the morphology of the sample. X-ray photoelectron spectroscopy (ESCALAB 250, Thermo Fisher Scientific, Waltham, MA, USA) was used to detect the surface chemical composition of the material and the chemical state of each element.

\subsection{Batch Adsorption Experiment}

In total, $0.80 \mathrm{~g}$ of $\mathrm{Pb}\left(\mathrm{NO}_{3}\right)_{2}$ was dissolved in deionized water to prepare a $500 \mathrm{mg} \cdot \mathrm{L}^{-1}$ $\mathrm{Pb}$ (II) standard solution. SMN-x series adsorbents and different initial concentrations of $\mathrm{Pb}$ (II) solutions were added into a $50 \mathrm{~mL}$ conical flask and stirred on a constant temperature oscillator for $12 \mathrm{~h}$. According to Equation (1), to calculate the amount of $\mathrm{Pb}$ (II) adsorbed by SMN-x series adsorbents:

$$
q_{e}=\frac{\left(C_{0}-C_{e}\right) v}{m}
$$

where $C_{0}\left(\mathrm{mg} \cdot \mathrm{L}^{-1}\right)$ and $C_{e}\left(\mathrm{mg} \cdot \mathrm{L}^{-1}\right)$ are the initial concentration and equilibrium concentration of $\mathrm{Pb}(\mathrm{II})$ in the solution, $V(\mathrm{~mL})$ is the volume of the solution, $m(\mathrm{~g})$ is the dosages of SMN-x series adsorbents. Through a single-factor static equilibrium experiment, the removal effect of $\mathrm{SMN}-\mathrm{x}$ series on $\mathrm{Pb}$ (II) was investigated, including the adsorbent dosage, initial $\mathrm{pH}$, contact time and initial $\mathrm{Pb}(\mathrm{II})$ concentration, etc., and the best experimental conditions were obtained. The $\mathrm{Pb}$ (II) concentration in the supernatant after centrifugation was measured independently three times using the inductively coupled plasma atomic emission spectrometer (ICP-OES) technique.

Safety evaluation of adsorption residue [29,30]: The extraction method was used to obtain the exchangeable $\mathrm{Pb}$ (II) content and the acid-soluble $\mathrm{Pb}$ (II) content to calculate the stable $\mathrm{Pb}(\mathrm{II})$ content in the residue. In total, $8 \mathrm{~mL}$ of $0.5 \mathrm{M} \mathrm{MgCl}_{2}$ and $0.1 \mathrm{~g}$ of the adsorption residue were mixed and shaken at $25^{\circ} \mathrm{C}$ for $20 \mathrm{~min}$, then passed through a $0.22 \mu \mathrm{m}$ filter membrane to collect the supernatant and ICP-OES was used to test the concentration to obtain exchangeable $\mathrm{Pb}$ (II). Following this, $8 \mathrm{~mL}$ of $1 \mathrm{M} \mathrm{NaAc}$ and $0.1 \mathrm{~g}$ residue were mixed and shaken at $25^{\circ} \mathrm{C}$ for $5 \mathrm{~h}$. Passing through a $0.22 \mu \mathrm{m}$ filter membrane to collect the supernatant, ICP-OES was used to test the concentration to obtain exchangeable acidsoluble $\mathrm{Pb}$ (II). The stable $\mathrm{Pb}$ (II) content in the residue can be obtained by subtracting the exchangeable $\mathrm{Pb}(\mathrm{II})$ and the acid-soluble $\mathrm{Pb}$ (II) from the total amount of $\mathrm{Pb}$ (II) adsorbed.

\section{Results and Discussion}

\subsection{Characterization of Adsorbents}

Figure 1 shows the adsorption on sepiolite and SMN-1, SMN-2, SMN-3, SMN-4 and SMN-6 at different initial concentrations of $\mathrm{Pb}(\mathrm{II})$. The result of batch adsorption tests showed that the SMN-3 prepared with bath time of $3 \mathrm{~h}$ had the best adsorption effect on $\mathrm{Pb}$ (II) among the different water bath times. Therefore, adsorbent SMN-3 was applied to subsequent study and characterization due to its admirable adsorption performance.

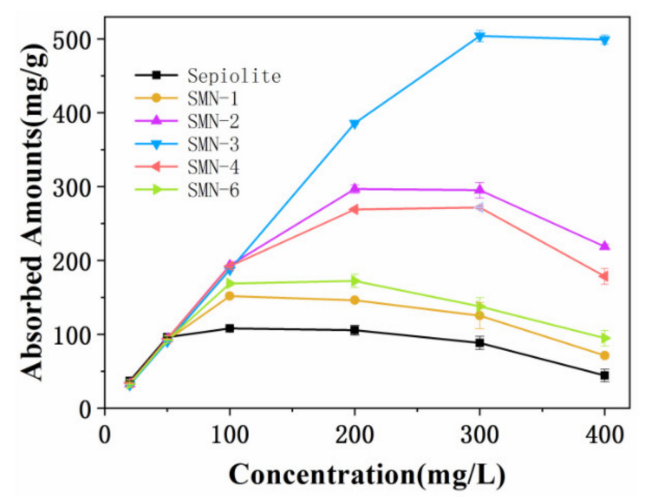

Figure 1. Effect of initial concentration on $\mathrm{Pb}(\mathrm{II})$ adsorption (dosage of $\mathrm{SMN}-\mathrm{x}$ was $25.00 \mathrm{mg}$, adsorption time was $12 \mathrm{~h}, \mathrm{pH}$ was 5 and temperature was $25^{\circ} \mathrm{C}$ ). 
Figure 2a was the XRD patterns of Sepiolite and SMN-3. As shown in Figure 2a, the characteristic peaks at $7.13^{\circ}, 20.26^{\circ}, 23.55^{\circ}$ and $34.7^{\circ}$ were the diffraction of sepiolite, which was consistent with the sepiolite standard card JCPDS PDF No. 29-1492 [31]. In addition, sepiolite also contained some impurity peaks, and $29.47^{\circ}$ belonged to the diffraction peak of calcium carbonate (JCPDS PDF No. 47-1743) [32,33]. The diffraction peaks at $9.43^{\circ}, 9.63^{\circ}$ and $28.85^{\circ}$ corresponded to talc [32]. After being modified with oxalic acid, the diffraction peak of the sample at $7.13^{\circ}$ disappeared and some new diffraction peaks showed up at $15.00^{\circ}, 24.37^{\circ}, 29.86^{\circ}, 38.10^{\circ}$ and $50.08^{\circ}$, which was consistent with the standard card of $\mathrm{CaC}_{2} \mathrm{O}_{4} \cdot \mathrm{H}_{2} \mathrm{O}$ (JCPDS PDF No. 35-10914) [29], indicating that $\mathrm{CaC}_{2} \mathrm{O}_{4} \cdot \mathrm{H}_{2} \mathrm{O}$ was formed after heating by the water bath.
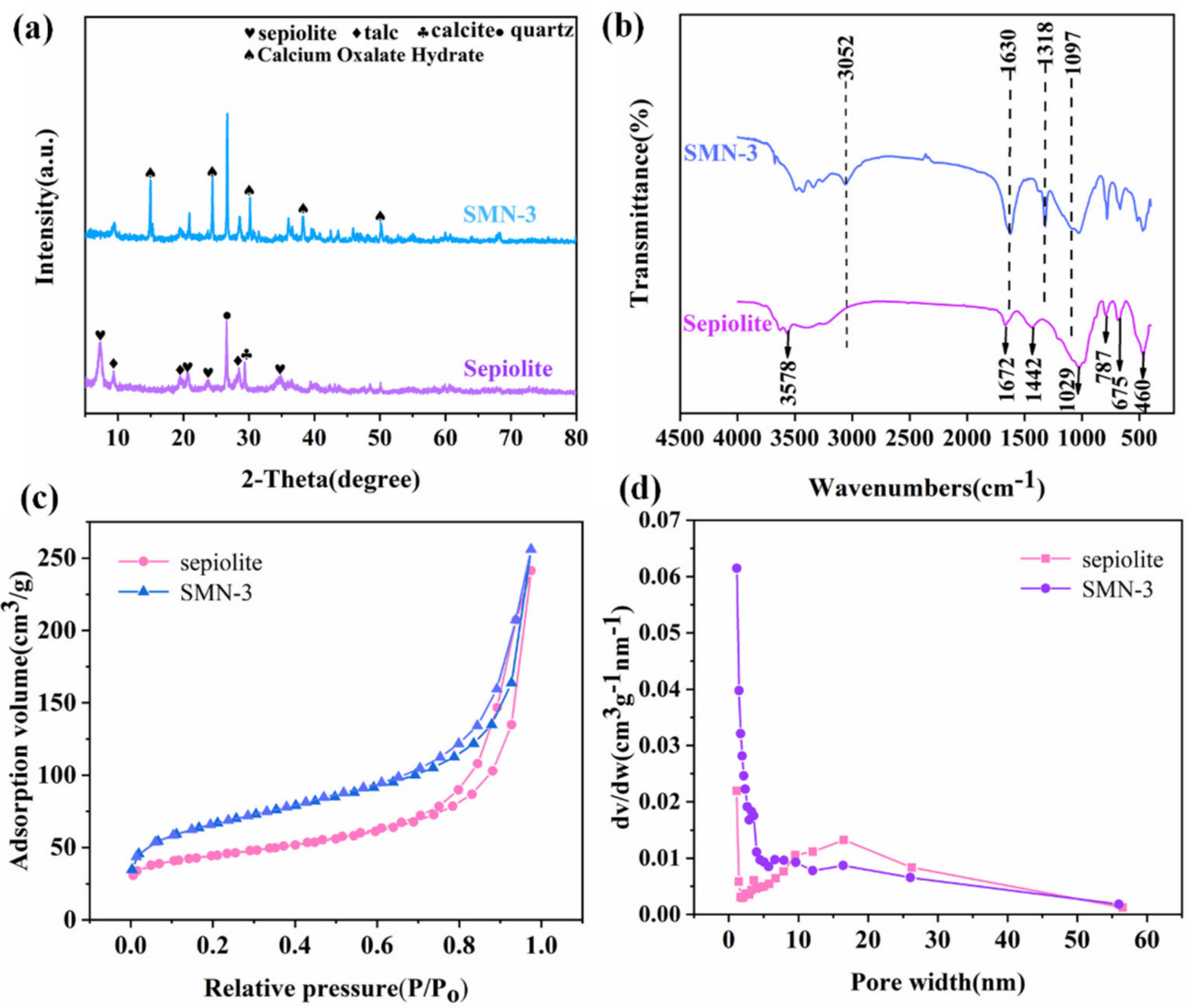

Figure 2. (a) XRD patterns of Sepiolite and SMN-x3; (b) FTIR; (c) $\mathrm{N}_{2}$ adsorption/desorption isotherms; (d) Pore diameter distribution curve.

Figure $2 \mathrm{~b}$ shows the FTIR spectra of sepiolite and SMN-3. For sepiolite, the band at around $1672 \mathrm{~cm}^{-1}$ was attributed to the hydroxyl bending vibration of water molecules [29]. The band at around $1442 \mathrm{~cm}^{-1}$ was consistent with the anti-symmetric and symmetric stretching of $\mathrm{CO}_{3}{ }^{2-}$, which confirmed the presence of carbonate [12,24]. The $3578 \mathrm{~cm}^{-1}$ band was ascribed to the $-\mathrm{OH}$ stretching vibration related to the $\mathrm{Mg}(\mathrm{II})$ in the octahedral coordination [31]. The $787 \mathrm{~cm}^{-1}$ band was Si-O antisymmetric stretching vibration, and the $675 \mathrm{~cm}^{-1}$ and $460 \mathrm{~cm}^{-1}$ bands were attributed to Si-O flexural vibration and antisymmetric flexural vibration [34-38]. After being modified, the bands of sepiolite at $1672 \mathrm{~cm}^{-1}, 787 \mathrm{~cm}^{-1}$, $675 \mathrm{~cm}^{-1}$ and $460 \mathrm{~cm}^{-1}$ still existed [16,27]. The new peaks at around $3052 \mathrm{~cm}^{-1}$ were due to the $-\mathrm{OH}$ stretching vibration of $\mathrm{CaC}_{2} \mathrm{O}_{4} \cdot \mathrm{H}_{2} \mathrm{O}$ and $1630 \mathrm{~cm}^{-1}$ was attributed to the bending vibration of $\mathrm{C}=\mathrm{O}, 1318 \mathrm{~cm}^{-1}$ and $1097 \mathrm{~cm}^{-1}$ owing to the stretching vibration of $\mathrm{C}-\mathrm{C}$ and C-OH [29], which indicated the complex of $\mathrm{CaC}_{2} \mathrm{O}_{4} \cdot \mathrm{H}_{2} \mathrm{O}$ and sepiolite was formed.

The $\mathrm{N}_{2}$ adsorption-desorption isotherm of the samples in Figure 2c shows that the isotherms of sepiolite and SMN-3 were type IV and H3 hysteresis loop, which indicated that there were slit holes in the material $[39,40]$. The pore size distribution curve in Figure $2 \mathrm{~d}$ 
showed that SMN-3 adsorbent was mainly microporous and mesoporous, and sepiolite was mesoporous $[20,31]$. The specific surface area and pore volume of sepiolite and SMN-x were calculated with the Barrett-Joyner-Halenda (BJH) method. As Table 1 shows, with the water bath time increasing the pore volume and average pore diameter of SMN-x changed slightly. The surface area first increased and then decreased and the specific surface area of the adsorbent reached the maximum $\left(234.14 \mathrm{~m}^{2} \cdot \mathrm{g}^{-1}\right)$ at the $3 \mathrm{~h}$.

Table 1. Textural properties of as-prepared composites.

\begin{tabular}{cccc}
\hline Material & $\begin{array}{c}\text { Specific Surface } \\
\text { Area }\left(\mathbf{m}^{\mathbf{2}} \cdot \mathbf{g}^{-\mathbf{1}} \mathbf{)}\right.\end{array}$ & $\begin{array}{c}\text { Pore Volume } \\
\left(\mathbf{c m}^{\mathbf{3}} \cdot \mathbf{g}^{\mathbf{- 1}} \mathbf{)}\right.\end{array}$ & $\begin{array}{c}\text { Average Pore } \\
\text { Diameter }(\mathbf{n m})\end{array}$ \\
\hline Sepiolite & 159.92 & 0.351 & 1.134 \\
SMN-1 & 203.53 & 0.409 & 1.133 \\
SMN-2 & 185.14 & 0.387 & 1.130 \\
SMN-3 & 234.14 & 0.390 & 1.165 \\
SMN-4 & 181.28 & 0.393 & 1.139 \\
SMN-6 & 191.05 & 0.451 & 1.143 \\
SMN-9 & 192.61 & 0.402 & 1.168 \\
\hline
\end{tabular}

The microstructure and morphological changes of sepiolite and SMN-3 were observed by SEM and TEM (Figure 3). Figure 3a shows that the sepiolite had fibrous morphology. Figure $3 \mathrm{~b}$ displays that $\mathrm{SMN}-3$ mainly presented lamellar and fibrous morphology in which the fibrous one was sepiolite and the lamellar one was $\mathrm{CaC}_{2} \mathrm{O}_{4} \cdot \mathrm{H}_{2} \mathrm{O}$. The similar structure could be seen as well from the TEM images of SMN-3 (Figure 3c). Figure 3d shows the selected area diffraction image, crystal diffraction spots and diffraction rings indicated the presence of polycrystals in the selected area. The interplanar spacings were $0.4208,0.2536$, and $0.1694 \mathrm{~nm}$ by calculation, which was the same as $\mathrm{CaC}_{2} \mathrm{O}_{4} \cdot \mathrm{H}_{2} \mathrm{O}(004),(305)$ and (533) and proved that $\mathrm{CaC}_{2} \mathrm{O}_{4} \cdot \mathrm{H}_{2} \mathrm{O}$ with flaky morphology was formed.
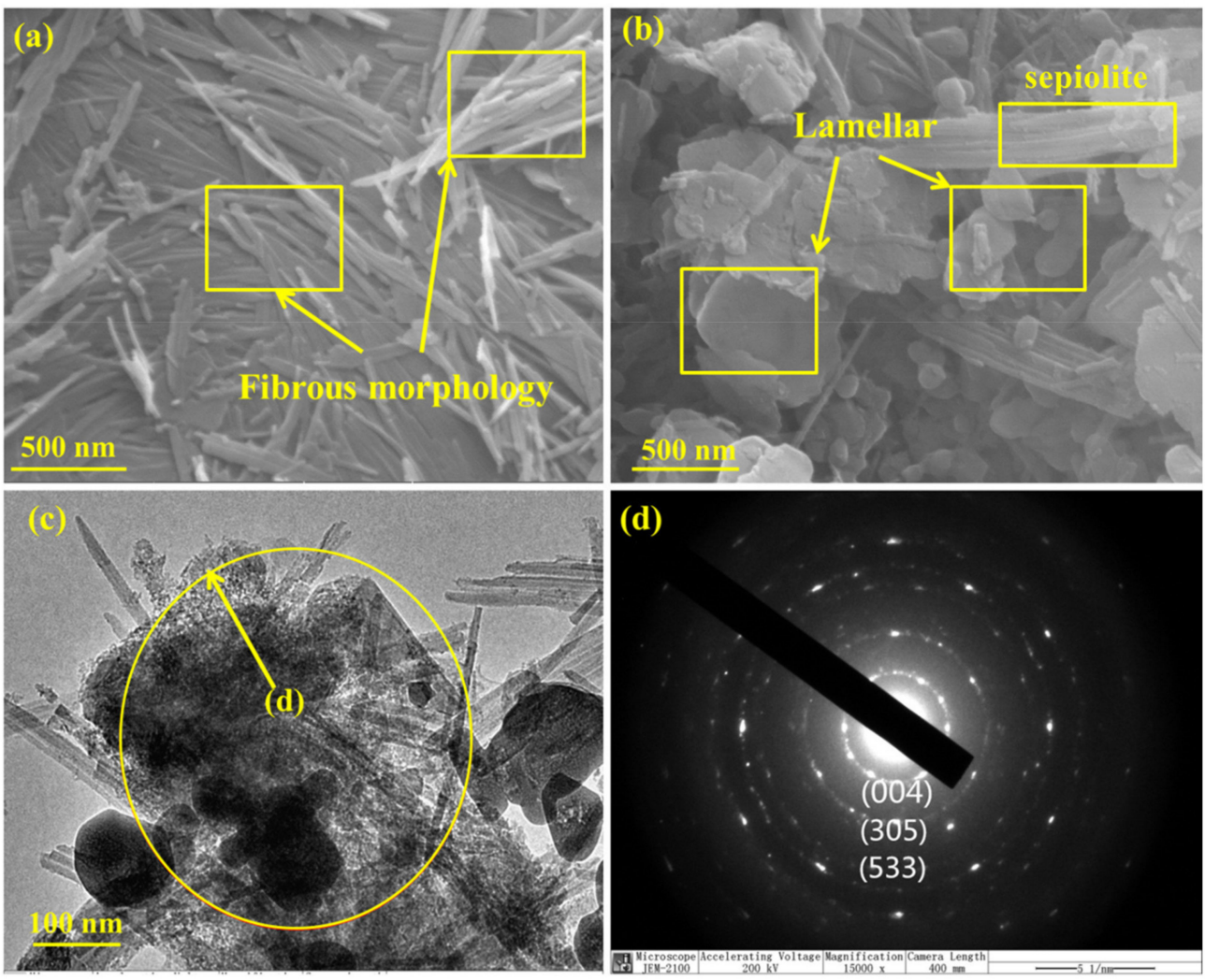

Figure 3. (a,b) SEM images of sepiolite and SMN-3; (c) TEM image of SMN-3; (d) the selected area electron diffraction analysis. 


\subsection{Effect of the Initial Concentration and Contact Time}

As shown in Figure 4a, the maximum adsorption capacity of sepiolite for $\mathrm{Pb}(\mathrm{II})$ is only $107.97 \mathrm{mg} \cdot \mathrm{g}^{-1}$. The maximum adsorption capacity of SMN-3 can reach $504.07 \mathrm{mg} \cdot \mathrm{g}^{-1}$, which is about four times higher than the maximum adsorption capacity of sepiolite. In addition, with the increasing of the initial concentration, the $\mathrm{Pb}(\mathrm{II})$ adsorption capacity of all materials increased. After reaching the adsorption equilibrium, the adsorption capacity decreased slightly. This may be due to the higher initial concentration of $\mathrm{Pb}(\mathrm{II})$, the active sites of the sample being quickly occupied, and a large amount of $\mathrm{Pb}(\mathrm{II})$ adsorbing and covering the surface of the sample to prevent further adsorption reactions.
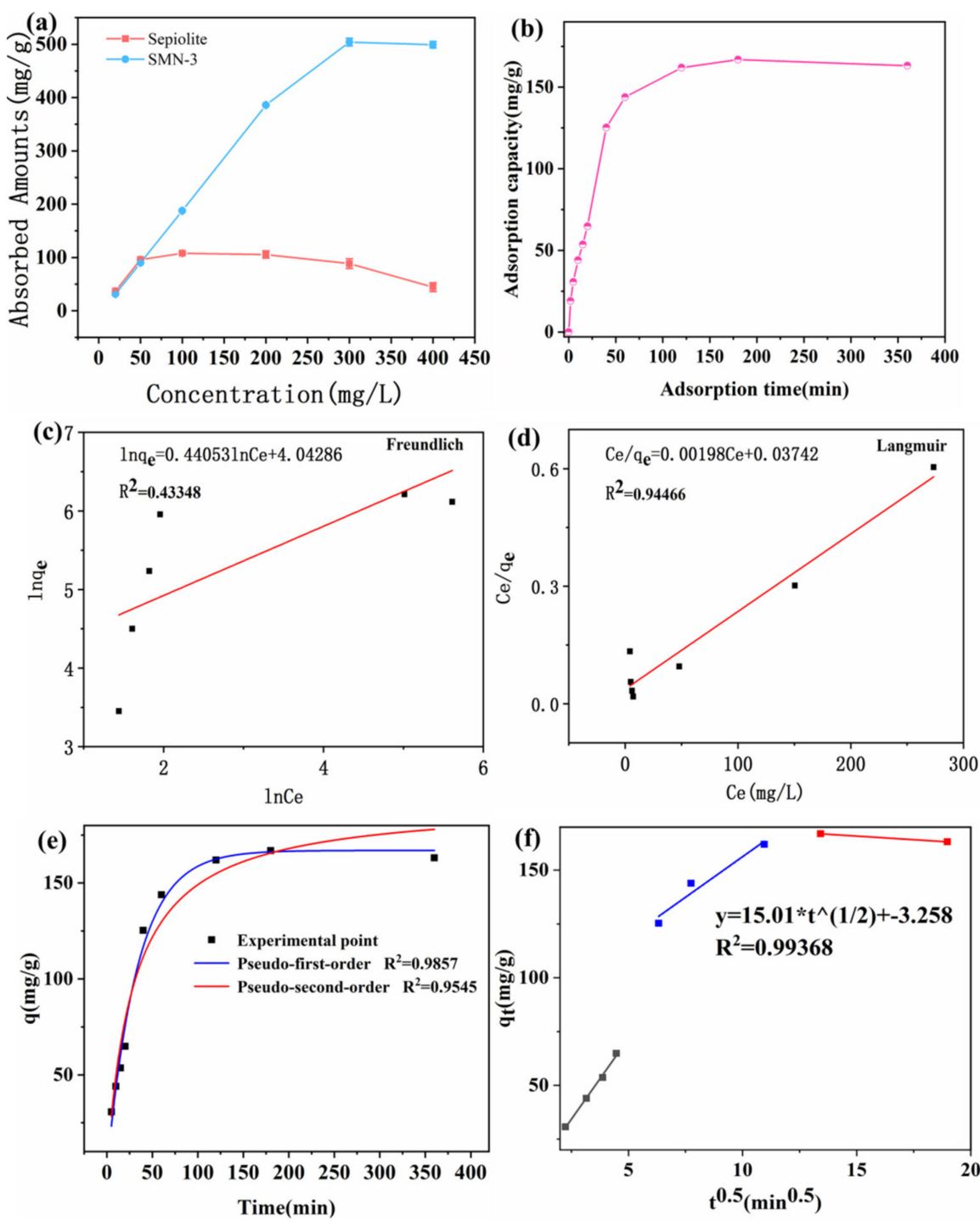

Figure 4. (a) Adsorption capacity of sepiolite and SMN-3 (dosage $=25.00 \mathrm{mg}, t=12 \mathrm{~h}, \mathrm{pH}=5, \mathrm{~T}=25^{\circ} \mathrm{C}$ ); (b) the effect of contact time on adsorption (dosage $=25.00 \mathrm{mg}, \mathrm{Pb}(\mathrm{II})$ initial concentration $=100 \mathrm{mg} \cdot \mathrm{L}^{-1}$, $\left.\mathrm{pH}=5, \mathrm{~T}=25^{\circ} \mathrm{C}\right) ;(\mathbf{c}, \mathbf{d})$ a linear fit of Freundlich and Langmuir model; $(\mathbf{e}, \mathbf{f})$ nonlinear adsorption kinetics model and intra-particle diffusion model.

Figure $4 \mathrm{~b}$ showed the effect of contact time on the adsorption equilibrium of $\mathrm{Pb}$ (II) on SMN-3. The adsorption capacity increased exponentially in the first $60 \mathrm{~min}$, slowly increased during 60-180 $\mathrm{min}$, and reached adsorption equilibrium after $180 \mathrm{~min}$. This was due to the initial rapid diffusion of $\mathrm{Pb}$ (II) from the solution to the surface of SMN-3. As the adsorption progressed, the active sites on the surface of the material were completely occupied and lead oxalate precipitation was formed to wrap the surface of the material. 
With the concentration of $\mathrm{Pb}(\mathrm{II})$ continuing to decrease, the mass transfer force decreased, which prevented the material from further reacting with $\mathrm{Pb}$ (II) so that adsorption rate slowed down. Therefore, in order to ensure that the adsorbent can reach adsorption equilibrium at different concentrations, the adsorption time of $12 \mathrm{~h}$ was selected.

\subsection{Adsorption Isotherms and Kinetics}

The Freundlich (Equation (2)) and Langmuir (Equation (3)) equations were used to calculate the adsorption isotherm data, respectively:

$$
\begin{gathered}
\frac{C_{e}}{q_{e}}=\frac{1}{q_{e} b}+\frac{C_{e}}{q_{m}} \\
\ln q_{e}=\ln k_{F}+\frac{1}{n} \ln c_{e}
\end{gathered}
$$

where $q_{e}\left(\mathrm{mg} \cdot \mathrm{g}^{-1}\right)$ and $q_{m}\left(\mathrm{mg} \cdot \mathrm{g}^{-1}\right)$ are the amount of $\mathrm{Pb}(\mathrm{II})$ adsorbed at equilibrium and the maximum adsorption capacity. $C_{e}\left(\mathrm{mg} \cdot \mathrm{L}^{-1}\right)$ is the equilibrium concentration of $\mathrm{Pb}(\mathrm{II})$ in the solution, and $b\left(\mathrm{~L} \cdot \mathrm{mg}^{-1}\right)$ is the Langmuir adsorption equilibrium constant. $K_{F}$ and $n$ are Freundlich adsorption equilibrium parameters related to adsorption capacity and adsorption strength.

The isotherm fitting curves are shown in Figure $4 c, d$, and the fitting data are listed in Table 2. Considering theoretical constrains and the determination coefficient $\left(R^{2}\right)$ values, it was calculated that the Langmuir model $\left(R^{2}>0.9447\right)$ simulated the adsorption isotherms of $\mathrm{Pb}(\mathrm{II})$ much higher than the Freundlich model $\left(\mathrm{R}^{2}>0.4335\right)$, suggesting that the major reaction of SMN-3 mainly occupied in monolayer molecular covering and chemical adsorption [41]. Besides, the maximal adsorption capacity of $\mathrm{SMN}-3$ for $\mathrm{Pb}$ (II) based on the result of the Langmuir model was $505.05 \mathrm{mg} \cdot \mathrm{g}^{-1}$, approaching the experimental value $\left(504.07 \mathrm{mg} \cdot \mathrm{g}^{-1}\right)$. At the same time, another comparison with previous papers was implemented, as shown in Table 3. Obviously, the SMN-3 was a promising adsorbent for wastewater treatment.

\begin{tabular}{|c|c|c|c|c|c|c|c|}
\hline \multicolumn{8}{|c|}{ Isotherm Models } \\
\hline & & \multicolumn{3}{|c|}{ Langmuir Isotherm } & \multicolumn{3}{|c|}{ Freundlich Isotherm } \\
\hline$T(\mathrm{~K})$ & $\begin{array}{c}q_{\mathrm{e}, \exp } \\
\left(\mathrm{mg} \cdot \mathrm{g}^{-1}\right)\end{array}$ & $\begin{array}{c}b \\
\left(\mathrm{~L} \cdot \mathrm{mg}^{-1}\right)\end{array}$ & $\begin{array}{c}q_{\mathrm{m}} \\
\left(\mathrm{mg} \cdot \mathrm{g}^{-1}\right)\end{array}$ & $R^{2}$ & $\begin{array}{c}K_{\mathrm{F}} \\
\left(\mathrm{mg} \cdot \mathrm{g}^{-1}\right)(\mathrm{L} \cdot \mathrm{mg})^{1 / \mathrm{n}}\end{array}$ & $1 \cdot n^{-1}$ & $R^{2}$ \\
\hline 298 & 504.07 & 0.053 & 505.05 & 0.9447 & 56.99 & 2.27 & 0.4335 \\
\hline \multicolumn{8}{|c|}{ Adsorption Kinetics } \\
\hline & & \multicolumn{3}{|c|}{ pseudo-first-order } & \multicolumn{3}{|c|}{ pseudo-second-order } \\
\hline $\mathrm{C}_{\mathrm{o}}\left(\mathrm{mg} \cdot \mathrm{L}^{-1}\right)$ & $\begin{array}{c}q_{\mathrm{e}, \exp } \\
\left(\mathrm{mg} \cdot \mathrm{g}^{-1}\right)\end{array}$ & $\begin{array}{c}q_{\mathrm{e}, \mathrm{cal}} \\
\left(\mathrm{mg} \cdot \mathrm{g}^{-1}\right)\end{array}$ & $\begin{array}{c}k_{1} \\
\left(\min ^{-1}\right)\end{array}$ & $R^{2}$ & $\begin{array}{c}q_{\mathrm{e}, \mathrm{cal}} \\
\left(\mathrm{mg} \cdot \mathrm{g}^{-1}\right)\end{array}$ & $\left(\mathrm{k} \cdot(\mathrm{min} \cdot \mathrm{mL})^{-1}\right)$ & $R^{2}$ \\
\hline 100 & 166.89 & 166.98 & 0.03005 & 0.9857 & 192.27 & $1.796 \times 10^{-4}$ & 0.9545 \\
\hline
\end{tabular}

Table 2. Adsorption isotherm and adsorption kinetics models of SMN-3.

Table 3. Comparison of the adsorption capacities of various adsorbents for $\mathrm{Pb}(\mathrm{II})$.

\begin{tabular}{cccc}
\hline Adsorbents & $\boldsymbol{q}_{\boldsymbol{m}}\left(\mathbf{m g} \cdot \mathbf{g}^{-\mathbf{1}}\right)$ & $\mathbf{p H}$ & Reference \\
\hline KNTs & 89.00 & 6.0 & {$[13]$} \\
$\mathrm{MSEP}_{\mathrm{Sep}-\mathrm{Fe}_{3} \mathrm{O}_{4}-\mathrm{MnO}_{2}}$ & 97.00 & 4.5 & {$[23]$} \\
SDNF & 131.58 & 6.0 & {$[24]$} \\
Z2 & 638.90 & 6.0 & {$[26]$} \\
SMHFS & 446.98 & 6.0 & {$[29]$} \\
LMBC & 175.25 & 7.0 & {$[34]$} \\
SMN-3 & 787.90 & 6.0 & {$[39]$} \\
& 476.25 & 5.5 & {$[40]$} \\
\end{tabular}


To better understand the adsorption behavior, the pseudo-first order (Equation (4)) and the pseudo-second order nonlinear model (Equation (5)) were used to calculate the adsorption physical parameters [42], respectively.

$$
\begin{gathered}
q_{t}=q_{e 1} \cdot\left[1-\exp \left(-k_{t} \cdot t\right)\right] \\
q_{t}=\frac{q_{e 2}^{2} \cdot k_{2} \cdot t}{\left[k_{2} \cdot\left(q_{e 2}\right) \cdot t+1\right]}
\end{gathered}
$$

where $q_{e 1}$ and $q_{e 2}$ are the adsorption capacity of $\mathrm{Pb}$ (II) attached to the equilibrium. $q_{t}\left(\mathrm{mg} \cdot \mathrm{g}^{-1}\right)$ is the adsorption capacity of $\mathrm{Pb}(\mathrm{II})$ at any time $(\mathrm{t}) \cdot k_{1}\left(\mathrm{~L} \cdot \mathrm{min}^{-1}\right)$ and $k_{2}\left(\mathrm{~g} \cdot(\mathrm{mg} \cdot \mathrm{min})^{-1}\right)$ represent the pseudo-first order and pseudo-second order rate constants, respectively.

The fitting curve of the kinetic model is shown in Figure 4e-f, and Table 2 shows the corresponding parameters. The results showed that the $\mathrm{R}^{2}(0.9857)$ of the pseudo-first-order model obtained by calculation was higher than the pseudo-second-order kinetic model $\left(R^{2}=0.9545\right)$, which indicated that the pseudo-first-order kinetics can better describe the adsorption process on SMN-3 composites. Therefore, it can be concluded that chemical adsorption dominated the $\mathrm{Pb}$ (II) adsorption behavior [37].

The intra-particle diffusion model is presented as Equation (6).

$$
q_{t}=k_{p i} \cdot t^{1 / 2}+c_{i}
$$

Furthermore, the intra-particle diffusion model presented high $R^{2}$ values, which meant it was the rate-limiting step and the adsorption process was particle-diffusion controlled [43,44]. The fitting curve consisted of three linear stages, where the first and second stages were associated both with boundary layer and intra-particle diffusion steps. The third stage was the equilibrium condition of adsorption.

\subsection{Effects of Initial $\mathrm{pH}$}

The $\mathrm{pH}$ was a vital factor for the distribution of solution $\mathrm{Pb}(\mathrm{II})$ and the adsorption performance. As shown in Figure 5a, with the rise of $\mathrm{pH}$ value, the SMN-3 adsorption capacity gradually increased and remained stable at $156.33 \mathrm{mg} \cdot \mathrm{g}^{-1}$ between $\mathrm{pH} 5-6$. At $\mathrm{pH} 2$, the adsorption capacity decreased to $111.87 \mathrm{mg} \cdot \mathrm{g}^{-1}$. The above analysis suggested that the SMN-3 can be used in a few extreme environments owing to the high acid resistance. As the zeta potentials show in Figure $5 b$, with the $\mathrm{pH}$ increasing, the negative charge on the $\mathrm{SMN}-3$ surface increased, which promoted the electrostatic attraction interaction of $\mathrm{Pb}(\mathrm{II})$. In summary, the effect of $\mathrm{pH}$ further revealed that the adsorption process mechanism included electrostatic attraction interaction. In the subsequent experiments, considering the optimal $\mathrm{Pb}(\mathrm{II})$ removal efficiency, the $\mathrm{pH}$ value of 5 was used for the adsorption study.

\subsection{Effects of Adsorbent Dosage}

It is a critical factor for industrial-scale applications to achieve minimal adsorption cost and removal efficiency of the targeted contaminants. As observed in Figure 5c, with the adsorbent dosage increasing, the maximum adsorption capacity decreased from $153.34 \mathrm{mg} \cdot \mathrm{g}^{-1}$ to $46.15 \mathrm{mg} \cdot \mathrm{g}^{-1}$ and the $\mathrm{Pb}$ (II) removal rate increased from $16.02 \%$ to $93.04 \%$. When the adsorbent dosage was $25.00 \mathrm{mg}$, the adsorption capacity of $\mathrm{Pb}$ (II) reached the maximum value. However, when the dosage was greater than $50 \mathrm{mg}$, the removal rate was stable at $93 \%$, which was due to the saturation of available active sites and particle aggregation of high adsorbent dosage at the constant initial $\mathrm{Pb}$ (II) centration. Based on the aforementioned results, in the follow-up study $25.00 \mathrm{mg}$ was identified as the optimal dosage, which can not only ensure a good $\mathrm{Pb}$ (II) removal rate but also a good adsorption capacity. 

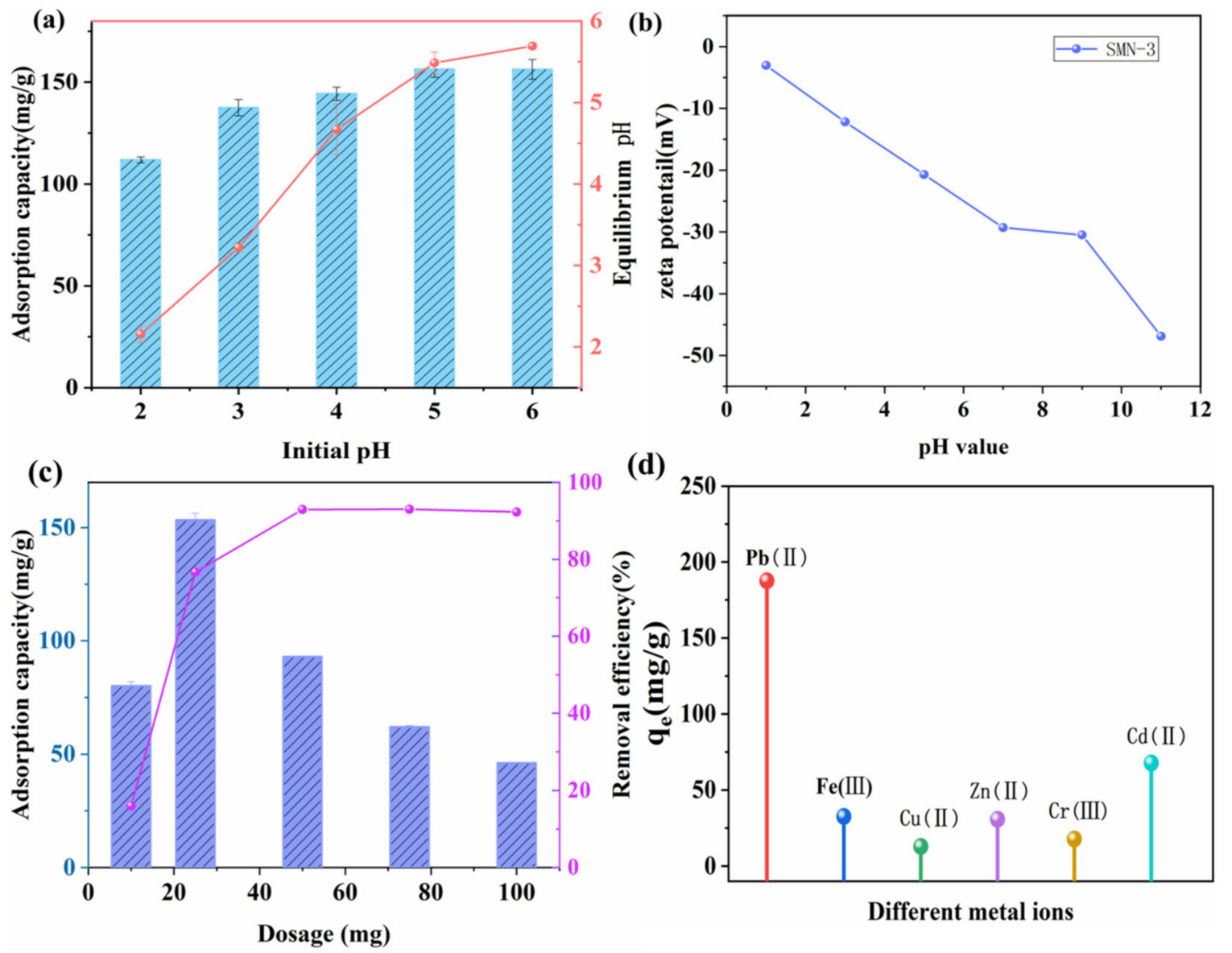

Figure 5. (a) Effect of solution $\mathrm{pH}\left(\right.$ dosage $=25 \mathrm{mg}, \mathrm{Pb}(\mathrm{II})$ initial concentration $\left.=100 \mathrm{mg} \cdot \mathrm{L}^{-1}, \mathrm{t}=12 \mathrm{~h}, \mathrm{~T}=25^{\circ} \mathrm{C}\right) ;(\mathbf{b}) \mathrm{Zeta}$ potentials; (c) effect of adsorbent dosage ( $\mathrm{Pb}(\mathrm{II})$ initial concentration $\left.=100 \mathrm{mg} \cdot \mathrm{L}-1, \mathrm{t}=12 \mathrm{~h}, \mathrm{pH}=5, \mathrm{~T}=25^{\circ} \mathrm{C}\right)$; $(\mathrm{d})$ the adsorption efficiency of SMN-3 for various ions (dosage $=25 \mathrm{mg}$, various metal ions initial concentration $=100 \mathrm{mg} \cdot \mathrm{L}^{-1}$, $\mathrm{t}=12 \mathrm{~h}, \mathrm{pH}=5, \mathrm{~T}=25^{\circ} \mathrm{C}$ ).

\subsection{Adsorption Efficiency of SMN-3 for Various Ions}

Various metal ions, like $\mathrm{Pb}(\mathrm{II}), \mathrm{Fe}(\mathrm{III}), \mathrm{Cu}(\mathrm{II}), \mathrm{Zn}(\mathrm{II}), \mathrm{Cr}(\mathrm{III})$ and $\mathrm{Cd}(\mathrm{II})$, contained in actual wastewater were identified as poisonous water contaminants. From the inset of Figure $5 \mathrm{~d}$, the adsorption capacity of SMN-3 on different metal ions, such as $\mathrm{Pb}$ (II), $\mathrm{Fe}(\mathrm{III})$, $\mathrm{Cu}(\mathrm{II}), \mathrm{Zn}(\mathrm{II}), \mathrm{Cr}(\mathrm{III})$ and $\mathrm{Cd}(\mathrm{II})$, was compared. Consequently, the adsorption capacity of $\mathrm{Pb}$ (II) was $187.64 \mathrm{mg} \cdot \mathrm{g}^{-1}$, which was higher than other metal ions. The removal efficiency of $\mathrm{Fe}(\mathrm{III}), \mathrm{Cu}(\mathrm{II}), \mathrm{Zn}(\mathrm{II}), \mathrm{Cr}(\mathrm{III})$ and $\mathrm{Cd}(\mathrm{II})$ was $32.51,12.88,30.79,17.79$ and $67.73 \mathrm{mg} \cdot \mathrm{g}^{-1}$, respectively. The ion exchange reaction is easier to proceed with and conducive to the adsorption of $\mathrm{Pb}(\mathrm{II})$ because the $\mathrm{K}_{\mathrm{SP}}$ (solubility product) value of lead oxalate $\left(8.51 \times 10^{-10}\right)$ is smaller than zinc oxalate $\left(1.38 \times 10^{-9}\right)$ and ferrous oxalate $\left(3.2 \times 10^{-7}\right)$ and other $\mathrm{K}_{\mathrm{SP}}$ values. Hence, the above analysis showed that $\mathrm{SMN}-3$ can be used in practical applications as an admirable potential adsorbent with high selectivity.

\subsection{Safety Evaluation of Adsorption Residue}

The safety of the lead-loaded adsorbent is vital for practical industrial applications. The total amount of $\mathrm{Pb}(\mathrm{II})$ in the adsorbent residue collected after adsorption was calculated to be $190.01 \mathrm{mg} \cdot \mathrm{g}^{-1}$. According the adsorption residue test, the acid-soluble $\mathrm{Pb}(\mathrm{II})$ in the residue was calculated to be $2.95 \mathrm{mg} \cdot \mathrm{g}^{-1}$ and the exchangeable $\mathrm{Pb}(\mathrm{II})$ content was $4.20 \mathrm{mg} \cdot \mathrm{g}^{-1}$. Therefore, the stable $\mathrm{Pb}$ (II) content was $182.87 \mathrm{mg} \cdot \mathrm{g}^{-1}$, accounting for $96.24 \%$ of the total lead content. The results indicated that in the residue after adsorption had perfect stability and safety. 


\subsection{Adsorption Mechanism}

The XRD characterization of SMN-3 after adsorption of $\mathrm{Pb}(\mathrm{II})$ is presented in Figure 6a. After adsorption, the characteristic diffraction peaks of $\mathrm{CaC}_{2} \mathrm{O}_{4} \cdot \mathrm{H}_{2} \mathrm{O}$ on SMN-3 disappeared. In addition, the new diffraction peaks at $26.75^{\circ}, 27.08^{\circ}$, etc. were accorded with the $\mathrm{PbC}_{2} \mathrm{O}_{4}$ (JCPDS: 14-0803) [29]. The results indicated that the active substance $\mathrm{CaC}_{2} \mathrm{O}_{4} \cdot \mathrm{H}_{2} \mathrm{O}$ in the adsorbent is mainly to remove $\mathrm{Pb}(\mathrm{II})$ via ion exchange reaction. The chemical reaction equation is shown below in Equation (7).

$$
\mathrm{CaC}_{2} \mathrm{O}_{4} \cdot \mathrm{H}_{2} \mathrm{O}(\mathrm{s})+\mathrm{Pb}^{2+} \rightarrow \mathrm{PbC}_{2} \mathrm{O}_{4}(\mathrm{~s})+\mathrm{Ca}^{2+}+\mathrm{H}_{2} \mathrm{O}
$$

(a)
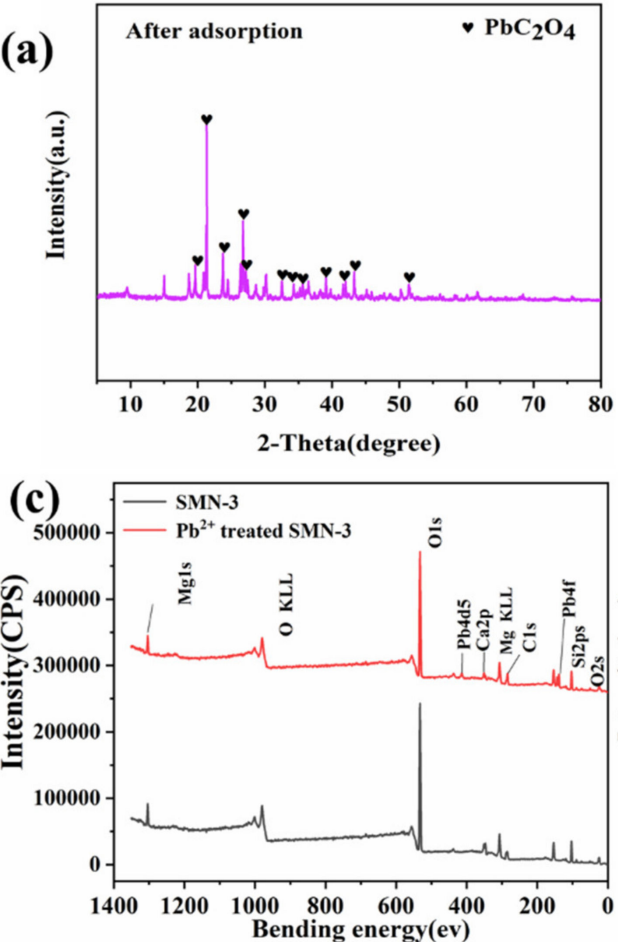

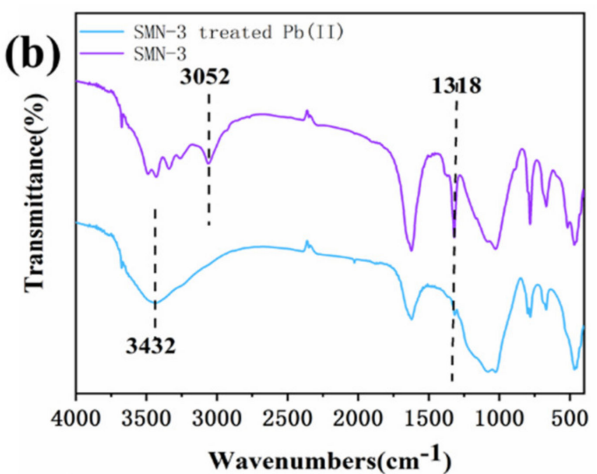

(d)

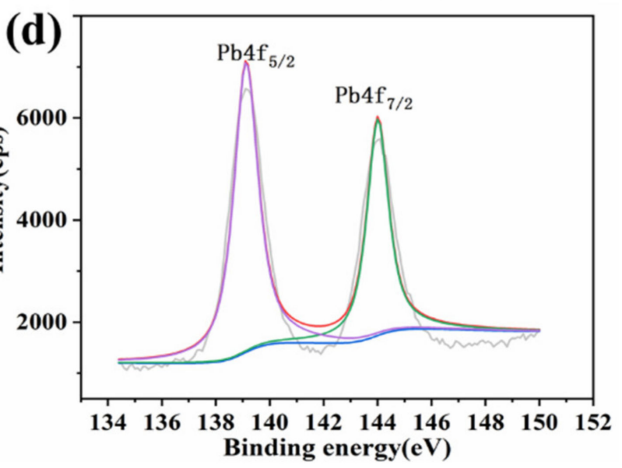

(e)

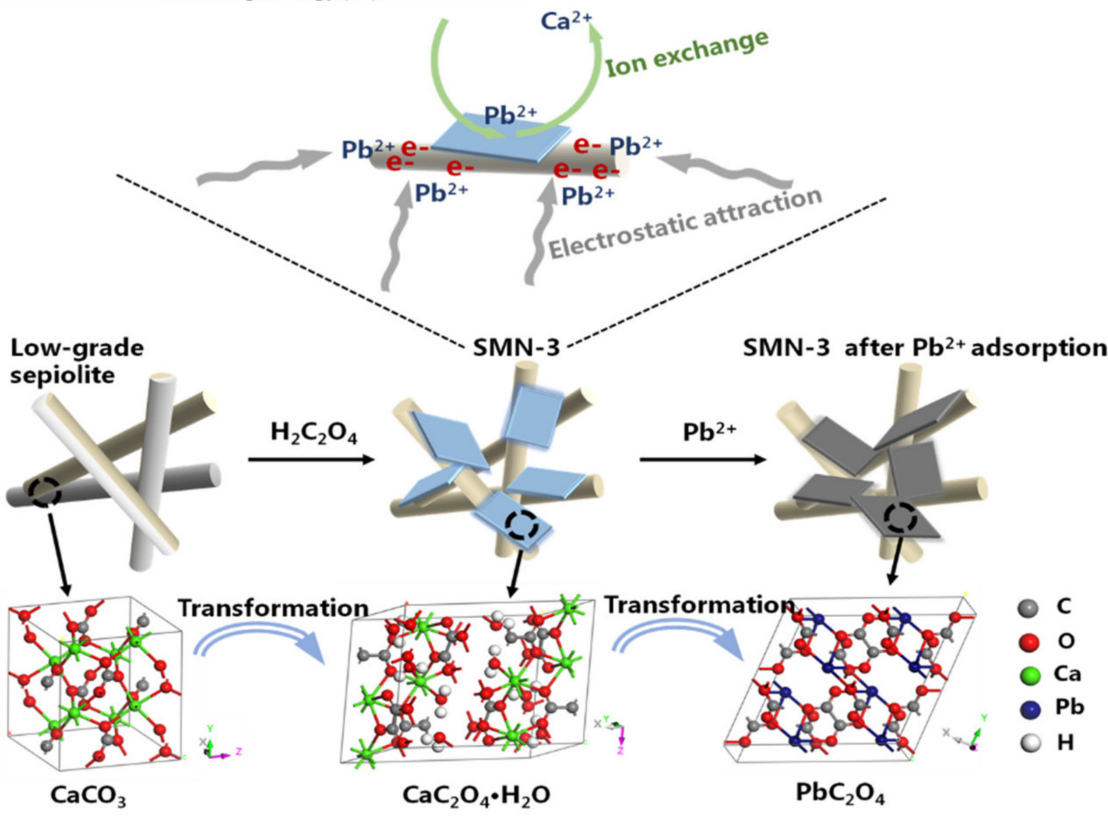

Figure 6. (a) XRD pattern of SMN-3 after adsorption; (b) FTIR spectrum of SMN-3 before and after adsorption; (c) Full-scan XPS spectra of before and after absorption; (d) high-resolution scan of Pb4f (e) adsorption mechanism. 
The FTIR characterization of $\mathrm{SMN}-3$ before and after $\mathrm{Pb}(\mathrm{II})$ adsorption is shown in Figure $6 \mathrm{~b}$. From the comparison, the band in $3052 \mathrm{~cm}^{-1}$ of SMN-3 disappeared after $\mathrm{Pb}$ (II) adsorption, which due to $\mathrm{CaC}_{2} \mathrm{O}_{4} \cdot \mathrm{H}_{2} \mathrm{O}$ was transformed into $\mathrm{PbC}_{2} \mathrm{O}_{4}$ without bound water The band in $1318 \mathrm{~cm}^{-1}$ disappearing was related to the formation of $\mathrm{PbC}_{2} \mathrm{O}_{4}$ [29]. The results suggest that $\mathrm{CaC}_{2} \mathrm{O}_{4} \cdot \mathrm{H}_{2} \mathrm{O}$ participated in the adsorption of $\mathrm{Pb}$ (II) via ion exchange. In order to further explore the composition changes of SMN-3 during the adsorption process, the full-scan XPS spectra before the Ca atomic percentage declined from $1.60 \%$ for $\mathrm{SMN}-3$ to $0.8 \%$ for $\mathrm{Pb}$ (II)-treated SMN-3, and the peak intensity significantly declined. Moreover, in the high-resolution spectrum of $\mathrm{Pb}$ (Figure 6d), the value in binding energy between the two peaks $\mathrm{Pb} 4 \mathrm{f}_{5 / 2}(139.1 \mathrm{eV})$ and $\mathrm{Pb} 4 \mathrm{f}_{7 / 2}(144.0 \mathrm{eV})$ of $\mathrm{Pb} 4 \mathrm{f}$ orbital spin splitting was $4.9 \mathrm{eV}[24,41]$. These results suggested that $\mathrm{Pb}(\mathrm{II})$ existed on the surface of SMN-3 after adsorption was performed. As observed in Figure $6 \mathrm{c}$, in addition to $\mathrm{Mg}, \mathrm{O}, \mathrm{Si}$, $\mathrm{C}$ and $\mathrm{Ca}$ elements, a new $\mathrm{Pb} 4 \mathrm{f}$ signal appeared after adsorption with an atomic percentage of $0.65 \%$, indicating that $\mathrm{Pb}(\mathrm{II})$ had been adsorbed on the SMN-3 surface [45,46]. Overall, Figure 6e summarizes this study's proposed adsorption mechanism. According to the analyses, the low-grade sepiolite was firstly chelated with oxalic acid and then nanosheets of $\mathrm{CaC}_{2} \mathrm{O}_{4} \cdot \mathrm{H}_{2} \mathrm{O}$ were formed. After treating by $\mathrm{Pb}$ (II) solution, $\mathrm{CaC}_{2} \mathrm{O}_{4}$ transformed to $\mathrm{PbC}_{2} \mathrm{O}_{4}$. During the adsorption process, ion exchange was noted as the main mechanism between $\mathrm{Ca}$ (II) and $\mathrm{Pb}$ (II) and it was also accompanied by electrostatic attraction.

\section{Conclusions}

The calcium carbonate impurity associated with low-grade sepiolite was converted to calcium oxalate by co-heating sepiolite with oxalic acid. The XRD, FTIR, BET and SEM profiles demonstrated that the SMN-3 adsorbent was successfully prepared and exhibited the highest specific surface area $\left(234 \mathrm{~m}^{2} \cdot \mathrm{g}^{-1}\right)$. Its $\mathrm{Pb}(\mathrm{II})$ adsorption capacity $\left(504.07 \mathrm{mg} \cdot \mathrm{g}^{-1}\right)$ was noted to be five times superior compared to that of sepiolite $\left(105.57 \mathrm{mg} \cdot \mathrm{g}^{-1}\right)$. The $\mathrm{Pb}(\mathrm{II})$ sorption process was conformed with the quasi-first-order kinetic, intra-particle model and Langmuir isotherm model, i.e., intra-particle diffusion and monolayer chemisorption. The optimal $\mathrm{pH}$ value was determined to be 5 , whereas the optimum amount of adsorbent for the adsorption of $\mathrm{Pb}(\mathrm{II})$ was $25.00 \mathrm{mg}$. Moreover, $\mathrm{SMN}-3$ revealed high selectivity and safe operation. Furthermore, the adsorption of $\mathrm{Pb}$ (II) on the SMN-3 adsorbent was mainly driven by ion exchange, which was also accompanied to some extent by electrostatic attraction. Thus, this study provided a universal and sustainable strategy for the application of low-grade clay minerals.

Author Contributions: A.T. and H.X. conceived and designed the experiments; H.X. and J.H. performed the experiments; S.Z. and H.X. analyzed the data; J.L. and S.Z. contributed reagents/materials / analysis tools; H.X. wrote the paper. All authors have read and agreed to the published version of the manuscript.

Funding: We are greatly grateful for the National Natural Science Foundation of China (No. 51674293) and the Fundamental Research Funds for the Central Universities of Central South University (No. 1053320183687).

Informed Consent Statement: All authors have read and agreed to the published version of the manuscript.

Conflicts of Interest: There are no conflict of interest to declare.

\section{References}

1. Fu, F.; Wang, Q. Removal of heavy metal ions from wastewaters: A review. J. Environ. Manag. 2011, 92, 407-418. [CrossRef] [PubMed]

2. Alexander, J.A.; Ahmad Zaini, M.A.; Surajudeen, A.; Aliyu, E.N.U.; Omeiza, A.U. Surface modification of low-cost bentonite adsor-bents-A review. Part. Sci. Technol. 2018, 37, 538-549. [CrossRef]

3. Li, R.; Zhang, L.; Wang, P. Rational design of nanomaterials for water treatment. Nanoscale 2015, 7, 17167-17194. [CrossRef] [PubMed] 
4. Tavakoli, O.; Goodarzi, V.; Saeb, M.R.; Mahmoodi, N.M.; Borja, R. Competitive removal of heavy metal ions from squid oil under isothermal condition by CR11 chelate ion exchanger. J. Hazard. Mater. 2017, 334, 256-266. [CrossRef]

5. Khadem, S.S.M.; Mashhadzadeh, A.H.; Habibzadeh, S.; Munir, M.T.; Lima, E.C.; Saeb, M.R. A theoretical probe into the effects of material and operational variables on water purification with zeolite membranes. Microporous Mesoporous Mater. 2021, 320, 111070. [CrossRef]

6. Sharma, P. Efficiency of bacteria and bacterial assisted phytoremediation of heavy metals: An update. Bioresour. Technol. 2021, 328, 124835. [CrossRef]

7. Wang, Z.K. Low-cost hydrogel adsorbent enhanced by trihydroxy melamine and $\beta$-cyclodextrin for the removal of $\mathrm{Pb}(\mathrm{II})$ and $\mathrm{Ni}(\mathrm{II})$ in water. J. Hazard. Mater. 2021, 411, 125029. [CrossRef] [PubMed]

8. Ghani, N.; Jami, M.S.; Alam, M.Z. The role of nanoadsorbents and nanocomposite adsorbents in the removal of heavy metals from wastewater, A review and prospect. Pollution 2021, 7, 153-179.

9. Mullineaux, S.; McKinley, J.; Marks, N.; Scantlebury, D.; Doherty, R. Heavy metal (PTE) ecotoxicology, data review: Traditional vs. a compositional approach. Sci. Total. Environ. 2021, 769, 145246. [CrossRef]

10. Fang, D.; Zhang, R.; Deng, W.; Li, J. Highly efficient removal of Cu(II), Zn(II), Ni(II) and Fe(II) from electroplating wastewater using sulphide from sulphidogenic bioreactor effluent. Environ. Technol. 2012, 33, 1709-1715. [CrossRef] [PubMed]

11. Ghosh, P.; Samanta, A.N.; Ray, S. Reduction of COD and removal of $\mathrm{Zn}^{2+}$ from rayon industry wastewater by combined electro-Fenton treatment and chemical precipitation. Desalination 2011, 266, 213-217. [CrossRef]

12. Dong, W.K.; Lu, Y.; Wang, W.; Zhang, M.; Jing, Y.; Wang, A. A sustainable approach to fabricate new 1D and 2D nanomaterials from natural abundant palygorskite clay for antibacterial and adsorption. Chem. Eng. J. 2020, 382, 122984. [CrossRef]

13. Abukhadra, M.R.; Bakry, B.M.; Adlii, A.; Yakout, S.M.; El-Zaidy, M.E. Facile conversion of kaolinite into clay nanotubes (KNTs) of en-hanced adsorption properties for toxic heavy metals $\left(\mathrm{Zn}^{2+}, \mathrm{Cd}^{2+}, \mathrm{Pb}^{2+}\right.$, and $\left.\mathrm{Cr}^{6+}\right)$ from water. J. Hazard. Mater. 2019, 374, 296-308. [CrossRef] [PubMed]

14. Zhong, L.; Tang, A.; Yan, P.; Wang, J.; Wang, Q.; Wen, X.; Cui, Y. Palygorskite-template amorphous carbon nanotubes as a superior ad-sorbent for removal of dyes from aqueous solutions. J. Colloid Interface Sci. 2019, 537, 450-457. [CrossRef] [PubMed]

15. Fu, L.; Yan, Z.; Zhao, Q.; Yang, H. Novel 2D Nanosheets with Potential Applications in Heavy Metal Purification: A Review. Adv. Mater. Interfaces 2018, 5. [CrossRef]

16. Ruiz-Hitzky, E.; Darder, M.; Alcântara, A.C.; Wicklein, B.; Aranda, P. Recent Advances on Fibrous Clay-Based Nanocomposites. Adv. Polym. Sci. 2014, 267, 39-86.

17. Wang, Q.; Tang, A.; Zhong, L.; Wen, X.; Yan, P.; Wang, J. Amino-modified $\gamma$ - $\mathrm{Fe}_{2} \mathrm{O}_{3}$ /sepiolite composite with rod-like morphology for magnetic separation removal of Congo red dye from aqueous solution. Powder Technol. 2018, 339, 872-881. [CrossRef]

18. Wang, Q.; Cui, Y.; Huang, R.; Zhong, L.; Yan, P.; Zhang, S.; Zhao, Q.; Jiang, D.; Tang, A.; Yang, H. A heterogeneous Fenton reaction system of $\mathrm{N}$-doped $\mathrm{TiO}_{2}$ anchored on sepio-lite activates peroxymonosulfate under visible light irradiation. Chem. Eng. J. 2020, 383, 123142. [CrossRef]

19. Largo, F.; Haounati, R.; Akhouairi, S.; Ouachtak, H.; El Haouti, R.; El Guerdaoui, A.; Hafid, N.; Santos, D.M.; Akbal, F.; Kuleyin, A.; et al. Adsorptive removal of both cationic and anionic dyes by using sepiolite clay mineral as adsorbent: Experimental and molecular dynamic simulation studies. J. Mol. Liq. 2020, 318, 114247. [CrossRef]

20. Wang, Z.; Liao, L.; Hursthouse, A.; Song, N.; Ren, B. Sepiolite-Based Adsorbents for the Removal of Potentially Toxic Elements from Water: A Strategic Review for the Case of Environmental Contamination in Hunan, China. Int. J. Environ. Res. Public Health 2018, 15, 1653. [CrossRef]

21. Zang, J.H.; Yan, Z.; Ouyang, J.; Yang, H.; Chen, D. Highly dispersed sepiolite-based organic modified nanofibers for enhanced ad-sorption of Congo red. Appl. Clay Sci. 2018, 157, 76-85. [CrossRef]

22. Zhang, S.; Zhong, L.; Wang, J.; Tang, A.; Yang, H. Porous carbon-based $\mathrm{MgAlF}_{5} \cdot 1.5 \mathrm{H}_{2} \mathrm{O}$ composites derived from carbon-coated clay presenting super high adsorption capacity for Congo Red. Chem. Eng. J. 2021, 406, 126784. [CrossRef]

23. Liang, X.; Xu, Y.; Wang, L.; Sun, Y.; Lin, D.; Sun, Y.; Qin, X.; Wan, Q. Sorption of $\mathrm{Pb}^{2+}$ on mercapto functionalized sepiolite. Chemosphere 2013, 90, 548-555. [CrossRef] [PubMed]

24. Fayazi, M.; Afzali, D.; Ghanei-Motlagh, R.; Iraji, A. Synthesis of novel sepiolite-iron oxide-manganese dioxide nanocomposite and application for lead(II) removal from aqueous solutions. Environ. Sci. Pollut. Res. 2019, 26, 18893-18903. [CrossRef]

25. Li, J.; Ma, Y.; Wang, C.; Ling, Y.; Li, R. Adsorption kinetics and thermodynamics of Congo red from aqueous solutions onto organic sepiolite. Environ. Pollut. Control 2013, 35, 52-56.

26. Zheng, Y.A.; Xie, Y.T.; Wang, A.Q. Adsorption of $\mathrm{Pb}^{2+}$ onto Chitosan-Grafted-Poly (Acrylic Acid)/Acid)/Sepiolite Composite. Chin. J. Environ. Sci. 2009, 30, 2575-2579.

27. Zhou, Q.; Huang, J.; Zhang, X.; Gao, Y. Assembling polypyrrole coated sepiolite fiber as efficient particle adsorbent for chromium (VI) removal with the feature of convenient recycling. Appl. Clay Sci. 2018, 166, 307-317. [CrossRef]

28. Zhou, F.; Yan, C.; Zhang, Y.; Tan, J.; Wang, H.; Zhou, S.; Pu, S. Purification and defibering of a Chinese sepiolite. Appl. Clay Sci. 2016, 124-125, 119-126. [CrossRef]

29. Zeng, Q.; Huang, Y.; Huang, L.; Li, S.; Hu, L.; Xiong, D.; Zhong, H.; He, Z. A novel composite of $\mathrm{SiO}_{2}$ decorated with nano ferrous oxalate (SDNF) for efficient and highly selective removal of $\mathrm{Pb}^{2+}$ from aqueous solutions. J. Hazard. Mater. 2020, $391,122193$. [CrossRef] 
30. Shen, Z.; Hou, D.; Jin, F.; Shi, J.; Fan, X.; Tsang, D.C.; Alessi, D.S. Effect of production temperature on lead removal mechanisms by rice straw biochars. Sci. Total. Environ. 2019, 655, 751-758. [CrossRef]

31. Yao, Q.Z.; Yu, S.H.; Zhao, T.L.; Qian, F.J.; Li, H.; Zhou, G.T.; Fu, S.Q. Enhanced Potential Toxic Metal Removal Using a Novel Hierar-chical $\mathrm{SiO}_{2}-\mathrm{Mg}(\mathrm{OH})_{2}$ Nanocomposite Derived from Sepiolite. Minerals 2019, 9, 298. [CrossRef]

32. Sani, H.A.; Ahmad, M.B.; Saleh, T.A. Synthesis of zinc oxide/talc nanocomposite for enhanced lead adsorption from aqueous solu-tions. RSC Adv. 2016, 6, 108819-108827. [CrossRef]

33. De Lima, J.A.; Camilo, F.F.; Faez, R.; Cruz, S.A. A new approch to sepiolite dispersion by treatment with ionic liquids. Appl. Clay Sci. 2017, 143, 234-240. [CrossRef]

34. Zheng, S.; Xia, S.; Han, S.; Yao, F.; Zhao, H.; Huang, M. $\beta$-Cyclodextrin-loaded minerals as novel sorbents for enhanced adsorption of $\mathrm{Cd}^{2+}$ and $\mathrm{Pb}^{2+}$ from aqueous solutions. Sci. Total. Environ. 2019, 693, 133676. [CrossRef] [PubMed]

35. Alkan, M.; Demirbaş, Ö.; Çelikçapa, S.; Doğan, M. Sorption of acid red 57 from aqueous solution onto sepiolite. J. Hazard. Mater. 2004, 116, 135-145. [CrossRef]

36. Turhan, Y.; Turan, P.; Doğan, M.; Alkan, M.; Namli, H.; Demirbaş, Ö.; Doğan, M.; Namlı, H. Characterization and Adsorption Properties of Chemically Modified Sepiolite. Ind. Eng. Chem. Res. 2008, 47, 1883-1895. [CrossRef]

37. Jia, S.Q. Characterization and properties of sepiolite/polyurethane nanocomposites. Mater. Sci. Eng. A 2007, 445-446, 725-730.

38. Tekbaş, M.; Bektaş, N.; Yatmaz, H.C. Adsorption studies of aqueous basic dye solutions using sepiolite. Desalination 2009, 249, 205-211. [CrossRef]

39. Xu, C.; Shi, S.; Wang, X.; Zhou, H.; Wang, L.; Zhu, L.; Zhang, G.; Xu, D. Electrospun $\mathrm{SiO}_{2}-\mathrm{MgO}$ hybrid fibers for heavy metal removal, Characteriza-tion and adsorption study of $\mathrm{Pb}(\mathrm{II})$ and $\mathrm{Cu}(\mathrm{II})$. J. Hazard. Mater. 2020, 381, 120974. [CrossRef] [PubMed]

40. Li, H.; Wang, Y.; Chen, H.; Niu, B.; Zhang, W.; Wu, D. Synergistic mediation of polysulfide immobilization and conversion by a cata-lytic and dual-adsorptive system for high performance lithium-sulfur batteries. Chem. Eng. J. 2021, 406, 126802. [CrossRef]

41. Jia, Y.; Zhang, Y.; Fu, J.; Yuan, L.; Li, Z.; Liu, C.; Zhao, D.; Wang, X. A novel magnetic biochar/MgFe-layered double hydroxides composite removing $\mathrm{Pb}^{2+}$ from aqueous solution: Isotherms, kinetics and thermodynamics. Colloids Surfaces A Physicochem. Eng. Asp. 2019, 567, 278-287. [CrossRef]

42. Lima, E.C.; Sher, F.; Guleria, A.; Saeb, M.R.; Anastopoulos, I.; Tran, H.N.; Hosseini-Bandegharaei, A. Is one performing the treatment data of adsorption kinetics correctly? J. Environ. Chem. Eng. 2021, 9, 104813. [CrossRef]

43. Dudu, T.E.; Sahiner, M.; Alpaslan, D.; Demirci, S.; Aktas, N. Removal of As(V), Cr(III) and Cr(VI) from aqueous environments by-poly(acrylonitril-co-acrylamidopropyl-trimethyl ammoniumchloride)-based hydrogels. J. Environ. Manag. 2015, 161, $243-251$. [CrossRef] [PubMed]

44. Benhouria, A.; Islam, M.A.; Zaghouane-Boudiaf, H.; Boutahala, M.; Hameed, B.H. Calcium alginate-bentonite-activated carbon composite beads as highly effective adsorbent for meth-ylene blue. Chem. Eng. J. 2015, 270, 621-630. [CrossRef]

45. Ge, H.; Hua, T.; Chen, X. Selective adsorption of lead on grafted and crosslinked chitosan nanoparticles prepared by using $\mathrm{Pb}^{2+}$ as template. J. Hazard. Mater. 2016, 308, 225-232. [CrossRef]

46. Lyu, F.; Yu, H.; Hou, T.; Yan, L.; Zhang, X.; Du, B. Efficient and fast removal of $\mathrm{Pb}^{2+}$ and $\mathrm{Cd}^{2+}$ from an aqueous solution using a chi-tosan/Mg-Al-layered double hydroxide nanocomposite. J. Colloid Interface Sci. 2019, 539, 184-193. [CrossRef] 